\title{
Why I Write (And Why I Think Law Professors Generally Should Write)
}

\author{
YALE KAMISAR*
}

\section{TABLE OF CONTENTS}

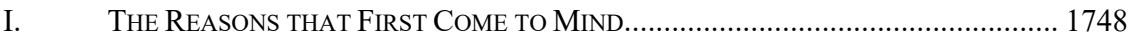

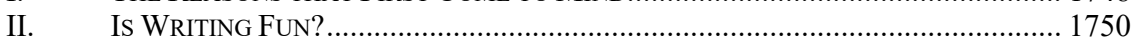

III. GEORGE ORWELL'S MOTIVES FOR WRITING.................................................... 1751

IV. WhY LAW PROFESSORS SHOULD WRITE .................................................... 1756

As my colleague James Boyd White has observed,

It may look as though we are all doing the same thing, as we huddle over our typewriters or computers, producing work called articles or books, but we are in fact often doing very different things, and I think it is important to recognize and value these differences, in ourselves and in others. ${ }^{1}$

There are not only differences in what we write but in whom it is that we write for. Unlike Professor White, ${ }^{2}$ I usually write as professional to professional. Again, unlike Professor White, ${ }^{3}$ I am fairly comfortable with "the voice and form" of the law review article.

Why do I write? Why do law professors generally write (at least those

\footnotetext{
* Professor of Law, University of San Diego; Professor of Law Emeritus, University of Michigan. I am indebted to my friend Al Slote for calling my attention to George Orwell's essay, Why I Write.

1. James Boyd White, Why I Write, 53 WASH. \& LEE L. REV. 1021, 1022 (1996).

2. See id. at 1035 ("I do not in the main write as professional to professional, but as person to person, or mind to mind.").

3. See id. at 1031 ("[T]he voice and form of the typical law review article were not congenial to me, and I could see no ready way to modify them for my purposes.").
} 
who do the same kind of writing I do)? I have asked myself this question more than once. Members of my family have asked me the same question quite a few times. It is not easy to explain why because the answers that first come to mind don't stand up when you think about it for a while.

\section{THE REASONS THAT FIRST COME TO MIND}

Young law professors have to write in order to gain tenure. ${ }^{4}$ And the writing requirement is a much more formidable one than it was when I began teaching in the 1950s. But that fails to explain why many law professors continue to write long after they have acquired tenure.

One might say that law professors continue to write because they want to attract the attention of faculty members at more prestigious law schools. But that doesn't explain why professors who started out at top schools, or moved there, continue to write. (To be sure, a few who started out at the very best schools have not been productive. It is also

4. Indeed, in recent years the word has spread that young people seeking teaching jobs should "publish" in order to improve their chances of getting hired in the first place. The competition for teaching jobs is so great and most law schools place so much emphasis on productivity that this development is quite understandable. Nevertheless, it may have some unfortunate consequences.

When I went into teaching some fifty years ago, it was a common pattern for young law school graduates to practice at a major law firm for two or three years before turning to law teaching. These young people were not expected to publish anything while they were in practice and few, if any, did.

Today, those who follow the old route to the legal academy are at a serious disadvantage. They must compete with those who have acquired Ph.D.s and/or J.S.D.s, as well as the basic law degree-which means that they must compete against those who have had much more time and opportunity to publish. (I know of at least one law school graduate who spent six years acquiring both a Ph.D. and a J.S.D. before going on the teaching market.) The sad truth is that the pressure to pile up billable hours is so great that it is virtually impossible for a busy young lawyer to find the time to publish something. For a long time, that did not matter. But it certainly matters nowadays.

I don't deny there may be a few exceptions - a few daring souls at busy law firms who somehow will manage to set aside two or three weeks to write an article. But this will probably do more harm than good.

It is almost impossible to write a good law review article in two or three weeks (unless you are as old as I am and can more or less repeat yourself). Moreover, it is extremely difficult to stand out among your peers when many of them, those working on advanced degrees, are spending three or four or five times as many hours working on their writing as you are on yours.

Every law faculty — and every student body—needs professors with different interests, perspectives, backgrounds, and style. At most places nowadays there is ample room for able people who have never even practiced law or ever wanted to do so. Indeed, some of my most valuable colleagues have turned out to be people who never went to law school (or might as well not have). In my judgment, however, legal education would suffer a grievous blow if young people who were too busy practicing law to "publish" were to be shut out of the legal academy by those who never ventured beyond the friendly confines of the university. 
true, however, that a goodly number of our most prolific law professors have always taught at the very best schools.)

Nor does it explain why law professors who have accomplished a great deal in their lives and have reached the age when most sane people retire continue to write. Why did Charles Alan Wright turn out so much material right up to the time he died at the age of $72 ?^{5}$ Why had Sam Dash completed the manuscript for a new book on search and seizure only a few months before he died at the age of $79 ?^{6}$ Why does Wayne LaFave not only continue to publish new and expanded editions of his three multivolume treatises, but also turn out new books and articles more than a decade after he became a professor emeritus? ${ }^{7}$

Many years ago, when one of my children was about twelve years old, he happened to get up in the middle of the night and notice that the light was on in my den. He asked me what I was doing. I told him I was working on a law review article. He asked me how much money I was going to be paid for it and I had to tell him I wasn't going to get paid anything. He was flabbergasted. Why, then, he wanted to know, was I doing this.

Because it was clear to me that my remarks had confirmed my son's suspicions that his dad was a bit goofy, and I wanted to eradicate that impression - as well as the look of incredulity on his face-I fumbled for an explanation. At the time, the best I could come up with was something like this: I am being paid "indirectly." Because I would soon be publishing a long article, I would probably get a larger raise than my less energetic colleagues. That could mean anywhere from $\$ 2000$ to $\$ 5000$ a year more in the bank.

5. Charles Alan Wright is best known as the lead author of the multivolume Federal Practice and Procedure treatise, which spans over fifty volumes. See CHARLES Alan Wright et al., Federal Practice and Procedure (3d ed. 1999). Wright passed away in July 2000.

6. Samuel Dash passed away in May 2004. His book has been published posthumously. See Samuel Dash, The Intruders: Unreasonable Searches and SEIZURES FROM KING JOHN TO JOHN ASHCROFT (2004).

7. Wayne LaFave has been a Professor Emeritus since 1993. In the past eleven years since taking emeritus status, he has published new and expanded editions of his three criminal law treatises. See, e.g., Wayne R. LaFave et al., Criminal Procedure (2d ed. 1999); Wayne R. LaFave, Search and Seizure: A Treatise on the Fourth AMENDMENT (3d ed. 1996); WAYNE R. LAFAVE, Substantive CRiminal LAW (2d ed. 2003). In addition, since taking Emeritus status, LaFave has co-authored three new editions of the casebook, Modern Criminal Procedure. See WAYNE R. LAFAVE ET AL., Modern Criminal Procedure (8th ed. 1994, 9th ed. 1999, and 10th ed. 2002). The 11 th edition of this casebook will be published in 2005 . 
I don't know whether my son believed that clumsy explanation, but I do know that I did not believe it myself. Even if you do receive a significantly larger raise than many of your colleagues because you have published more, if you divide the extra raise by the number of hours you logged producing a good-sized law review article (by that I mean doing the research, thinking about the substance and structure of the article, writing several drafts, making revisions, smoothing out the language, reading and correcting the page proofs), the hourly rate is astonishingly low.

I may be less efficient or more compulsive than most, but according to the calculations I have done, the hourly rate comes to less than twentyfive dollars an hour. I don't think I have to belabor the point that if money is what you are after, you can make a lot more, and make it a lot faster, by consulting or by teaching summer school somewhere. ${ }^{8}$

\section{IS WRITING FUN?}

If there isn't much money in writing, does one get pleasure from it? Over the years, I have heard people say that writing is fun. Indeed, at one point during the panel discussion that constituted the basis for this symposium, Professor Jonathan Macey said just that.

I must disagree. I do not deny that when, after many attempts and several drafts, I have managed to say something as well as I could (and yes, as well as I thought anybody could), I have felt a certain sense of satisfaction. But that doesn't make writing fun. A basketball player who guards Shaquille O'Neal as well as anybody may experience a great sense of satisfaction, but I doubt very much that he would call guarding "Shaq" "fun."

My colleague Steve Smith reports that, sometimes at least, he writes "because it provides an excuse not to read: writing is sometimes more fun or at least less painful than reading the sort of legal scholarship I would otherwise feel obligated to read." 9 My experience has been just the opposite. I usually spend too much time studying what others have had to say about the general subject I am going to write about because reading what others have to say is so much more pleasant than hammering out what I want to say. Postponing the actual writing is perhaps my greatest weakness as a writer. ${ }^{10}$

8. See Steven D. Smith, Legal Scholarship as Resistance to "Science," 41 SAN DiEGo L. REV. 1775, 1777 (2004).

9. See id. at 1776 .

10. If a person who has not yet written her first law review article were to ask me for advice, the first thing I would say is: Start writing as soon as you can. Cut to the chase. Starting to write doesn't mean you won't do any more "research." You almost 
Taking your child or grandchild to the circus may be fun. Playing tennis on a cool summer afternoon may be fun. A lot of things may be fun. But writing is not one of them. Writing is work and very good writing is very hard work.

Another word about work. When people say they work sixteen or eighteen hours a day, I can't help wondering how much time they spend on the phone or taking part in, or simply attending, meetings. I can talk sixteen or eighteen hours a day too. But writing - and of course I mean serious writing - is another matter. It requires so much focus, so much intensity, such total immersion in your work, that doing it five or six hours a day is quite an accomplishment.

George Orwell once talked about the experience of writing a book. I think what he had to say applies to writing a major law review article as well. He may have exaggerated a bit, but not, I think, by very much when he observed:

Writing a book is a horrible, exhausting struggle, like a long bout of some painful illness. One would never undertake such a thing if one were not driven on by some demon whom one can neither resist nor understand. For all one knows that demon is simply the same instinct that makes a baby squall for attention. ${ }^{11}$

\section{GEORGE ORWELL'S MOTIVES FOR WRITING}

As we all know, Orwell did not write law review articles (and I suspect that most people are happy that he did not waste his talent doing so), but some of the motives for writing he discussed strike a responsive chord. At one point, for example, Orwell reported that his "starting point" had often been a "a sense of injustice" and that for much of his career he started to write a book "because there is some lie that I want to expose," or "some fact to which I want to draw attention."12

Although I was not to read Orwell's essay until many years later,

certainly will. Don't assume that you do research for a given amount of time and then do the writing for another period of time. You will (or should) find yourself doing both, back and forth. The best way to find holes in your argument is to start writing. The best way to find out that you can't support something you assumed you could easily support is to start writing. Composing your thoughts will usually cause you to do more research, more focused research. And the additional research will often lead you to revise some of the statements you originally made - or to add some statements you should have made in the first place.

11. George Orwell, Why I Write, in The Orwell Reader 390, 395 (1956).

12. Id. at 394 . 
Orwell's comments provide a pretty good description of my motives for writing an article attacking the pre-Gideon rule regarding when indigent felony defendants could be furnished with appointed counsel. ${ }^{13}$ Under this rule, often called "the Betts rule" (after the case that established the rule $)^{14}$ or the "special circumstances" rule, an indigent defendant charged with a serious noncapital offense, such as armed robbery, had to represent himself unless there were "special circumstances," e.g., the defendant was mentally handicapped or the case was unusually complicated. Unfortunately, in practice the state courts in those jurisdictions which did not require the appointment of counsel in noncapital cases rarely, if ever, bothered to find out whether the "circumstances" were "special." 15

To use Orwell's language, the "lie" that I wanted to expose when I wrote my right to counsel article was the lie that a trial judge (or the prosecutor) could be counted on to protect the rights of an unrepresented defendant. Another "lie," as I viewed it, was that a record made without the input of any lawyer for the defense could establish that the unrepresented defendant was not disadvantaged by the absence of counsel. The record can "establish" no such thing. All that a record made without a defense lawyer can do, I maintained at some length, is fail to establish on its face that the unrepresented defendant appeared to be disadvantaged. ${ }^{16}$

13. See Yale Kamisar, The Right to Counsel and the Fourteenth Amendment: A Dialogue on "The Most Pervasive Right" of an Accused, 30 U. CHI. L. REV. 1 (1963).

14. Betts v. Brady, 316 U.S. 455 (1942), overruled by Gideon v. Wainwright, 372 U.S. 335 (1963).

15. In the Gideon case itself, when the defendant, a burglary defendant, asked the trial judge to appoint counsel for him, the judge responded that he could not do so because under Florida law "the only time the Court can appoint [c]ounsel ... is when [the defendant] is charged with a capital offense." Gideon, 372 U.S. at 337 (emphasis added).

16. What does it prove that the record reads well? How would it have read if the defendant had had counsel? The failure of the unrepresented defendant to develop a satisfactory theory, or if he does, to support it with adequate evidence, hardly demonstrates that he had a "fair trial." The same may be said for the failure to discard an alibi defense (the defense Mr. Betts used) or some other defense which is likely to do more harm than good. For the failure to know the "law" or possess the "facts" are the probable consequences of being without the aid of counsel inside and outside the courtroom.

One of the sad lessons a writer who lives a long life learns is that "there is no final victory. However great the triumph, it is ephemeral. Without further struggle it withers and dies." Francis A. Allen, On Winning and Losing, in LAW, INTELLECT, AND EDUCATION 11, 16 (1979). Unfortunately, the once discredited Betts $v$. Brady has resurfaced.

A decade after Gideon, the Court held that there is no flat right to appointed counsel in probation or parole revocations proceedings. In order to obtain appointed counsel, the probationer or parolee facing violation of his status and a return to prison must establish without a lawyer that there are substantial reasons that make revocation inappropriate and that these reasons "are complex or otherwise difficult to develop or present." Gagnon v. Scarpelli, 411 U.S. 778, 790 (1973). 
Orwell also told us that he was often moved to write because there is "some fact to which I want to draw attention."17 Once again, this rings a bell. Once again, the right to counsel article furnishes an illustration.

I thought it important to demonstrate that the very case that established the "special circumstances" rule, Betts v. Brady, was one in which a lawyer for the defense would have made a difference. Both the Court which had upheld Mr. Betts' conviction for armed robbery and the lower courts which had dealt with the case had assumed otherwise. ${ }^{18}$ But a long, hard look at the transcript of Mr. Betts' trial convinced me that the case was riddled with error.

To take but one example, the robbery victim did not pick Betts out of a lineup. The only person the victim was asked to identify was Betts - wearing a dark coat, dark glasses, and a handkerchief around his chin. ${ }^{19}$ Whose coat? Whose dark glasses and handkerchief? None of these items were ever offered into evidence. Indeed, the prosecution failed to establish that Mr. Betts ever owned a dark overcoat or a pair of dark glasses.

After reading and rereading the trial transcript many times and studying it for a number of weeks, ${ }^{20}$ I concluded that the following bootstraps operation occurred:

[The robbery victim] described ... the various items the robber was supposed to have worn; the police simply went out, begged or borrowed the requisite coat, glasses and handkerchief and slapped them on Betts; [the victim] then made his identification, based largely on the coat, glasses and handkerchief the police had put on Betts. ${ }^{21}$

Two decades after Gideon, the Court seemed to have suffered amnesia again when it held that, absent special circumstances, an indigent person is not entitled to appointed counsel when the state seeks to terminate her parental rights. The Court told us, on the basis of a record made without the assistance of counsel, that "the case presented no specially troublesome points of law, either procedural or substantive." Lassiter v. Dep't of Soc. Servs., 452 U.S. 18, 32 (1981).

17. ORWELL, supra note 11, at 394 .

18. "The simple issue," the Supreme Court told us, "was the veracity of the testimony for the State and that for the defendant." Betts, 316 U.S. at 472 . In denying Mr. Betts collateral relief, the state court had similarly concluded: "[I]n this case it must be said there was little for counsel to do on either side." Trial Record at 30, Betts v. Brady, quoted in Kamisar, supra note 13, at 42.

19. See Kamisar, supra note 13, at 43, 48-49.

20. I was able to take this much time because I was an academic, not a practicing lawyer. I didn't have to worry about how many hours I could bill. I could proceed on the basis that I had all the time in the world. (More about this later.)

21. Kamisar, supra note 13 , at 49. 
According to Orwell, one of the "great motives" for writing is:

Political purpose-using the word "political" in the widest possible sense. Desire to push the world in a certain direction, to alter other people's idea of the kind of society that they should strive after. ${ }^{22}$

Modifying Orwell's language a bit, I would have to say that a desire to alter people's ideas about the kind of criminal justice system they should strive after - especially the ideas held by people on the bench - has often been one of my motives. ${ }^{23}$ Of course, there are many people who have very different ideas about the kind of criminal justice system we ought to have. This means that people who have strong views about the subject are likely to get involved in what might be called "the politics of "crime"" or the "politics of "law and order.",

Because statistics have an almost magical appeal in a "fact"-minded culture such as ours, and, as renowned criminologist Lloyd Ohlin once observed, statistics are especially powerful when "they give a sense of solid reality (usually false) to something people vaguely apprehend," ${ }^{24}$ it is hardly surprising that "get-tough" politicians have long used (or should one say, misused?) statistics to prove that crime is "overwhelming our society" and that "criminal-coddling" courts and "soft-on-crime" liberals are largely to blame. ${ }^{25}$

If I had to limit myself to one example, I would point to the tactics of Senator John McClellan, who chaired the Senate subcommittee hearings on a bill, which, among other things, purported to repeal Miranda $v$. Arizona. ${ }^{26}$ When McClellan urged the need for and desirability of such

22. ORWELL, supra note 11, at 392-93.

23. I share the view that you cannot expect to convince even a single justice to adopt your position when you write a law review article "demonstrating a right to a minimum income, or to the lifestyle of your choice." Smith, supra note 8, at 1778. But I have always believed that the right law review article can have a significant impact on the courts when more "incremental" matters are at issue.

24. See Yale Kamisar, How to Use, Abuse-and Fight Back with-Crime Statistics, 25 OKLA. L. REV. 239, 239 (1972) (quoting Lloyd Ohlin); see also Lloyd E. Ohlin, The Effect of Social Change on Crime and Law Enforcement, 43 NOTRE DAME LAW. 834, 834 (1967-1968).

25. For articles maintaining or rejecting the view that the courts have had a major impact on the crime rate, see, e.g., Paul G. Cassell, Miranda's "Negligible" Effect on Law Enforcement: Some Skeptical Observations, 20 HARV. J.L. \& PUB. POL'Y 327 (1997); John J. Donohue III, Did Miranda Diminish Police Effectiveness?, 50 STAN. L. ReV. 1147 (1998); Fred E. Inbau, Public Safety v. Individual Civil Liberties: The Prosecutor's Stand, 53 J. CRIM. L. CRIMINOLOGY \& Police SCI. 85 (1962); Kamisar, supra note 24; Stephen J. Schulhofer, Bashing Miranda is Unjustified - and Harmful, 20 HARV. J.L. \& PUB. POL'Y 347 (1997).

26. 384 U.S. 436 (1966). The anti-Miranda provision, which became part of the Omnibus Crime Control and Safe Streets Act of 1968, was struck down two decades later in Dickerson v. United States, 530 U.S. 428 (2000). A 7-2 majority reminded the Congress that it "may not legislatively supersede our decisions interpreting and applying the Constitution." Id. at 437. 
legislation, he-

propped up in the rear of the Senate chamber a huge facsimile of the F.B.I.'s crime graph. The titles of key Supreme Court decisions were marked at the peaks along the rising line, to show the embarrassing parallel between Supreme Court activity on behalf of defendants and the crime rise. 27

\section{Senator McClellan then declared:}

[The] tone is set at the top. The Supreme Court has set a low tone in law enforcement, and we are reaping the whirlwind today. Look at [the crime graph] chart. Look at it and weep for your country. Crime spiraling upward and upward and upward. 28

To use Orwell's language one last time, again and again the use of crime statistics to frighten the public and to influence the judicial and legislative branches has turned out to be a lie (or at least, a misleading tactic) - one that people interested in the politics of crime should feel the urge to expose. Law professors may not have any special training in statistics. I certainly do not and I doubt that many who have written about the subject do, but here as elsewhere, whether the topic that becomes relevant is cost-benefit analysis or legal history or psychology or statistics, good writers should not give their opponents a free pass. Good writers do what has to be done.

To reach his full potential, it appears, a football player must constantly work out in the weight room. To fulfill their potential, it seems, legal writers must constantly educate themselves. They need not (and probably cannot) become historians or psychologists or criminologists, but they must educate themselves well enough to avoid being misled or confused or intimidated by arguments based on history or criminology or whatever. Good legal writers must educate themselves well enough to recognize - and to expose-lies or misleading arguments based on another discipline.

Collaboration with someone in another field is undoubtedly useful, but for one reason or another, such arrangements are often not feasible. Professor Donohue seems to have a special background and interest in statistics, but I had no idea he did until he decided to take issue with an empirical study maintaining that Miranda has had a significantly adverse and long-term effect on clearance rates for both violent and property

27. Fred P. Graham, The Self-Inflicted Wound 12 (1970).

28. 114 CONG. REC. 14,146 (1968). 
crimes. $^{29}$ I think Donohue's response to this claim is an important contribution to the "crime statistics" literature. ${ }^{30}$ But where was he in the early 1960s when I first began writing about the subject? ${ }^{31}$ When I really needed him? (Well, I figured out where he was - in elementary school.)

\section{WhY LAW PROFESSORS SHOULD WRITE}

As noted earlier, ${ }^{32}$ I am of the view that every law faculty should include a significant number of people who practiced law for a few years. It is not only because such people can bring certain insights to bear in their teaching and writing. It is also because I believe that such people are more likely to appreciate fully the many favorable conditions under which a writer in the legal academy works.

Even in the best of law firms (and I think I worked in one of them) it is not unusual for a young lawyer to discover that there simply is not enough time (or that the client cannot afford to pay for enough time) to research a point thoroughly. I am well aware that I practiced a long time ago, but if anything, I suspect the situation is worse today.

Law professors, on the other hand, do not have to worry about billable hours. They can think through and research exhaustively every problem or cluster of problems they meet along the way. The distance between professors and practitioners grows still wider when one remembers that practicing lawyers are not awarded research leave or summer grants in order to write.

Nor is that all. Law professors usually have access to much better libraries than their counterparts in practice. I can recall at least a dozen instances when law school research librarians dug up material for me that I thought could never be found. Further, it is not unusual for law professors to show drafts of their work to three or four colleagues and to receive helpful comments in return. Indeed, it is not unusual for law professors to send drafts of their work to people on other law faculties who teach in the same field. Moreover, in order to pick up helpful

29. See Donohue, supra note 25 , at $1151-80$.

30. See id. Donohue pointed out that the empirical study he was evaluating showed no significant relationship between Miranda and the clearance rate for murder - the most accurately reported crime. Id. at 1151-56. He suggested that Miranda's only real impact upon clearance rates may be that it prevents the police from obtaining information from custodial suspects about crimes other than those for which the suspects have been arrested.

31. See Yale Kamisar, On the Tactics of Police-Prosecution Oriented Critics of the Courts, 49 CoRnell L.Q. 436 (1963-1964); Yale Kamisar, Public Safety v. Individual Liberties: Some "Facts" and "Theories", 53 J. Crim. L. Criminology \& POlice SCI. 171, 184-93 (1962).

32. See supra note 4. 
criticism, a growing number of law professors present drafts of their work at various workshops held around the country.

Whenever I feel a bit discomfited and overworked, I cheer up by reminding myself of an incident that occurred while I was a second-year associate at Covington \& Burling. The firm encouraged young lawyers to represent indigent criminal defendants on appeal. So one day I found myself trying to overturn the drug conviction of one Warren Williams. ${ }^{33}$

Mr. Williams was illegally arrested on the street, ordered into a police car, and taken to a precinct building. As he was being led through a corridor to a room where arrestees are booked and thoroughly searched, Williams dropped a cigarette package containing heroin capsules to the floor. But his attempt to rid himself of the incriminating evidence before being searched failed. An officer walking behind him picked up the package and asked him what it was. Mr. Williams readily admitted that the package contained heroin. ${ }^{34}$

The district court denied the motion to suppress the heroin on the ground that Williams had "abandoned" it. I was fairly confident that I could convince the Court of Appeals that the heroin capsules should have been excluded as the "fruit" of the illegal arrest, i.e., the "throwing away" of the evidence was fatally tainted by the immediately preceding illegal arrest. But as I was preparing for the oral argument I thought of a new issue (or a potential issue): What if the government were to argue that even if the heroin capsules had been erroneously admitted, that ruling was "harmless error" because the defendant had voluntarily confessed that the package he was carrying contained cocaine?

I rushed into the library only to discover that since the 1880 case of Balbo v. People, ${ }^{35}$ the prevailing view was that the illegality of an arrest, or an immediately preceding search, did not affect the admissibility of a voluntary statement. I only had a day and a half to research the point, but the more research I did, the more I found cases against me.

It was clear that Williams' incriminating statement was voluntary. One might argue that Williams' statement had been coerced by the illegal arrest, but that argument seemed quite strained. Moreover, so far

33. See Williams v. United States, 237 F.2d 789 (D.C. Cir. 1956).

34. See the discussion of the case in Yale Kamisar, Illegal Searches or Seizures and Contemporaneous Incriminating Statements: A Dialogue on a Neglected Area of Criminal Procedure, 1961 U. ILL. L. F. 78, 127 n.224.

35. Balbo v. People, 80 N.Y. 484, 498-500 (1880). See generally Kamisar, supra note 34 . 
as I could tell, the courts had rejected it every time it had been made. I felt helpless.

Fortunately, the government never made the argument I feared so much. Therefore, the case turned solely on the admissibility of the physical evidence itself and on that issue I prevailed. But I never forgot the Balbo rule and the sick feeling it had given me.

I thought the Balbo rule was wrong. Perhaps it would be more accurate to say that I felt the Balbo rule was wrong. I felt that verbal evidence obtained from an illegally arrested person or from a person who had been illegally searched should be excluded as the fruit of the preceding illegality, just as physical evidence found on the person of an illegally arrested person is excluded. But I knew that I would have lost that argument if I had had to make it.

Five years later, when I was a young professor at the University of Minnesota Law School, I revisited the old Balbo rule. Now I had the time to research the subject to the last drop-for example, to trace the history and development of the Balbo rule and the history and development of more recent doctrines inconsistent with that rule. Now every time I encountered a problem, I had the time to think it through to the end. Now I could write draft after draft of an article on the subject until I was completely satisfied with it - no matter how long it took. (It took seven months.) ${ }^{36}$

When I wrote that article I wasn't any smarter than I had been five years earlier. But I could think about and write about the Balbo rule under more favorable conditions - under quite comfortable conditions - under working conditions that thousands of busy, hurried practitioners would greatly envy.

That strikes me as a very good reason why law professors should write.

36. With all immodesty, I both hoped and expected that my article would contribute to the eventual toppling of the Balbo rule, but I thought it would take another ten or twenty years for the rule to fall. As it turned out, it only took another two years. See Wong Sun v. United States, 371 U.S. 471, 485 (1963), stating that, under certain circumstances at least, "verbal evidence" which derives from an unlawful entry or an illegal arrest is "no less the 'fruit' of official illegality than the more common tangible fruits of the unwarranted intrusion." My article is cited at this point. Of course, this is what many law professors live for. 